\title{
Sustainability Reporting In A Global Context: What Are The Characteristics Of Corporations That Provide High Quality Sustainability Reports - An Empirical Analysis
}

Petra F.A. Dilling, New York Institute of Technology, Canada

\begin{abstract}
Over the last years, sustainable development has become one of the major issues that all global organizations are facing. The Global Reporting Initiative, located in the Netherlands and considered the leading authority world-wide, has developed what is currently considered the "common framework for sustainability reporting". The latest version of their reporting guidelines called G3 contains detailed instructions and standards on how to prepare sustainability reports. By using G3 guidelines, corporations show a strong commitment of continuous improvement of their sustainability reporting practices. The G3 guidelines are increasingly adopted by many global corporations and organizations. At present, more than 700 organizations voluntarily publish a sustainability report according to G3 guidelines. For the first time, this empirical study investigates if the better performing and/or governed corporations prepare their sustainability reports according to the G3 guidelines. The goal of this study is to determine if there are significant differences with regard to size, financial performance, capital structure, and corporate governance between firms that publish a G3 sustainability report to those that don't. Therefore, quantitative and qualitative variables of 124 randomly selected G3 reporting and non-G3 reporting corporations from 25 countries were analyzed. The results of this analysis show that corporations with the characteristics of being located in Europe, and/or being active in the energy or producing sector, and/or with a higher profit margin are more likely to produce high quality sustainability reports. Corporations with a higher long-term growth rate, on the other hand, are less likely to produce sustainability reports. The results of this unique study contribute directly to the knowledge of corporations providing voluntary CSR information in form of quality sustainability reports and the importance of the development of globally accepted sustainability reporting standards.
\end{abstract}

Keywords: sustainability reporting, global reporting initiative, G3 guidelines, corporate governance, empirical study, corporate social responsibility, CSR

\section{INTRODUCTION}

$\mathrm{n}$ the last few years, corporate social responsibility (CSR) and corporate sustainability have become some of the major developments for global corporations (Stanny and Ely 2008).Those two concepts are very much interlinked. Through sustainability reporting, also named non-financial reporting, corporations and organizations show their commitment for sustainable development which refers to "meeting the needs of the present without compromising the ability of future generations to meet their own needs"(CSR Quest 2009). In 1987, the general concept of sustainable development originated with a report named "Our Common Future" by the World Commission on Environment and Development (known as the Brundtland Commission) initiated by the United 
Nations (Brundtland Commission 1987). A few years later, in 1992, at the Earth Summit UN Conference on Environment and Development in Rio de Janeiro, 178 countries adopted a comprehensive action plan named Agenda 21 (UN conference on Environment and Development 1992) supporting sustainable development.

\section{Sustainability Reporting Overview}

To this date, there is no globally accepted definition of CSR or sustainability reporting. However, a common European understanding of what CSR means has emerged on the basis of the European Commission definition of CSR as "a concept whereby companies integrate social and environmental concerns in their business operations and in their interaction with their stakeholders on a voluntary basis" (The council and the European economic and social committee 2006).

Similarly, there is neither a single globally accepted definition of sustainability reporting nor a commonly accepted format that sustainability reporting should follow. However, sustainability reporting is growing at a fast pace. As of July 2007, nearly 20 percent of U.S. Fortune 500 companies have published a corporate sustainability report or citizenship report utilizing the Global Reporting Initiative (GRI) guidelines (UPHAM 2007). According to a 2008 report released by the Sustainable Investment Research Analyst Network (SIRAN), a working group of the Social Investment Forum (SIF) and conducted by the independent investment research firm KLD Research \& Analytics, Inc., more than half of the United States' 100 largest publicly traded companies reported on their sustainability efforts, and more than a third incorporated elements of the Global Reporting Initiative (GRI) sustainability reporting guidelines (SIRAN 2009). Additionally, KPMG, in its 2008 International Survey on Corporate Responsibility Reporting study, found that globally about $80 \%$ of the G250 companies now release corporate responsibility data (KPMG 2008).

This represents a dramatic rise in reporting for large global companies (G250) since the last KPMG survey in 2005. In addition, more than three-quarters of the G250 use the GRI Guidelines for their reporting and more than 700 global organizations voluntarily publish a sustainability report according to G3 guidelines.

\section{Reasons for Sustainability Reporting}

When looking at those growing numbers of corporations publishing sustainability reports it becomes evident that sustainability reporting has indeed become mainstream as it is claimed ever so often. There is a growing focus on the responsibilities of companies towards all of its stakeholders, the environment and the society in which it operates. The reason for this development is the fact that the expectations of the public on the role of global companies in society are increasing while trust in businesses is decreasing. This results in a call for better corporate governance, transparency and accountability. In addition, there is also increased pressure from governmental organizations or agencies (UN, OECD, EU, etc.) for corporations to look at and observe their triple bottom line (Boyd 2009).

In Europe, more and more individual countries make sustainability reporting mandatory, at least for certain types or sizes of corporations. Just recently, Denmark introduced requirements on sustainability reports for public corporations (Anonymous 2009). Some sort of sustainability reporting legislation exists also in Finland, Sweden, Belgium, the Netherlands and Germany for certain company categories, depending on size or sector of activity (Delbard 2008). The European Union itself, however, still only encourages voluntary sustainability reporting. "Because CSR is fundamentally about voluntary business behavior, an approach involving additional obligations and administrative requirements for business risks being counter-productive and would be contrary to the principles of better regulation" (Commission to the European parliament, the council and the European economic and social committee 2006).

Other international institutions or organizations, such as the UN (Global Compact) and OECD also rely heavily on voluntary initiatives. According to Runhaar and Lafferty (2009) CSR is primarily "to maintain legitimacy and to avoid bad publicity." Firms are said to implement CSR initiatives in order to maintain their market position, access to capital, the relationship with authorities, suppliers, and customers. CSR drivers that are also typically mentioned in literature are to inform shareholders (Hemingway and Maclagan 2004) and existing and potential 
employees (Garriga and Mele 2004). Other important CSR drivers are anticipated cost savings and resulting innovations and learning (Lankoski 2008). In essence, while engaging in CSR and implementing it into their corporate strategies, corporations hope to be able to improve their long-term performance and risk management. However, because of the extensive costs (Porter and Kramer 2006) for the implementation of a CSR program, in the past, researchers have questioned if CSR can lead to a competitive advantage for the corporations. Stephenson (2009) states that a competitive advantage can only be achieved successfully if CSR is been integrated in all aspects of operations with full support from the whole organization.

Lastly, another CSR driver that is named less often is the fact that the values of the managers are aligned with CSR. Castelo Branco and Rodriguez Lima (2008) in their research on competitive advantage due to CSR also examine environmental sensitivity and media exposure as one of the potential drivers for CSR.

\section{GRI and G3 Report}

The Global Reporting Initiative (GRI), located in Amsterdam in the Netherlands, developed out of the Coalition for Environmentally Responsible Economies (CERES) and the United Nations Environment Programme (UNEP). ${ }^{1}$ GRI describes itself as "a multi-stakeholder governed institution collaborating to provide the global standards in sustainability reporting" (GRI 2009B). Worldwide, the GRI is considered the leading authority on sustainability reporting after developing a commonly accepted framework for sustainability reporting. In June 2000, the GRI published the first set of Sustainability Reporting which contained reporting principles and specific content indicators to guide the voluntary preparation of sustainability reports. The latest version of their reporting guidelines called G3 (third generation), developed in 2006, contains detailed instructions and standards on how to prepare assured sustainability reports. By using G3 guidelines, corporations show a strong commitment of continuous improvement of their sustainability reporting practices. Organizations that decide to use the G3 framework selfdeclare an application level of $\mathrm{C}, \mathrm{C}+, \mathrm{B}, \mathrm{B}+, \mathrm{A}$, or A+ corresponding to the degree of thoroughness and third-party assurance achieved. G3 sustainability reports include three types of standard disclosures: organizational profile, performance indicators, and management approach (GRI 2009B). As mentioned before, the G3 guidelines are increasingly adopted by many global corporations and organizations (GRI 2009A).

\section{Sectors}

In the past, a few studies emphasized the importance of CSR commitment of corporations in specific sectors. For instance, the KPMG 2005 study found that 61 per cent of utility companies produced separate reports on corporate responsibility, with the average across all industries being at 33 per cent (Hobson 2005). Other empirical findings show that there is a significant difference between CSR reporting for different industries which they consider to be consistent with a stakeholder view of CSR. Sweeney and Coughlan (2008) suggest that firms report on CSR in line with expectations of key stakeholders, thereby "giving actually evidence for CSR reporting as another tool in the marketing communicators' toolbox". It is generally assumed that corporations in "high profile" industries, such as energy, pharmaceutical, utility, and mining corporations are more likely to provide more extensive CSR information to their stakeholders.

\section{Long-Term Growth}

In the existing literature, CSR has often been compared to a platform of growth. Danchev (2006), for instance, states that performance of an organization is coupled with its sustainable growth and behavior. The general idea behind this concept is the fact that managers implement CSR into the strategic objectives in order to achieve sustainable growth (IBM 2008). Depending on the status of each corporation in the CSR value chain, organizations will be able to experience growth that eventually will provide them with the possibility for long-term growth. If this is, in fact, true, it will be the corporation with long-term growth that is more likely to publish sustainability reports. Therefore, for this study, it is hypothesized that long-term growth in sales revenues is positively related to the publication of a G3 report.

\footnotetext{
${ }^{1}$ For more information on the history of the GRI please see GRI Briefing paper (GRI 2009A).
} 


\section{Access to Equity and Long-Term Debt}

A new segment of investors interested in so called socially responsible investments (SRI) has developed over the last years. In fact, between 1995 and 2005, investments of professionally managed assets grew from US \$7 trillion to US \$24.4 trillion, while the share of these assets invested in socially responsible investments grew from US $\$ 639$ billion to $\$ 2.29$ trillion (Social Investment Forum 2006). The SRI industry is growing in importance and has to be taken very seriously (Nilsson 2007).Therefore, it is anticipated that corporations with need for financing will be more likely to provide enhanced sustainability reporting in order to attract these investors with strong interest in sustainable operations. For this study, it is assumed that the issuance of new equity and long-term debt is positively related to the publication of a G3 report.

\section{Corporate Governance}

The concept of CSR is not a stand-alone concept. In order to be successful, CSR needs to be integrated with the overall mission and the resulting strategies of the organization. This includes an efficient inter-linkage between corporate governance and CSR program. According to Kolk (2008), many multinationals have recently started to pay attention to board supervision and structuring of sustainability responsibilities in addition to compliance, ethics and external verification. In order to meet this challenge, many corporations are adopting a long-term perspective by applying sustainability-oriented approaches to corporate reporting at a large scale. In this respect, sustainability can be interpreted as an attempt by companies "[...] to broaden the debate in a way that allows them to meet an ever shifting corporate governance agenda. Sustainability reporting aims to provide stakeholders with a clear picture of company values and principles, governance, and management values." (Anonymous 2003). Additionally, PainterMorland (2006) emphasizes the importance of corporate governance in developing a successful CSR program. The author points out that without a proper alignment of the corporate governance framework with CSR activities, the CSR initiative cannot provide a competitive advantage. Therefore, for this study, it is anticipated that a higher level of corporate governance is positively related to the publication of a G3 report.

\section{Financial Performance}

As CSR activities of global companies are increasing so does sustainability reporting. In prior studies on this subject, an increase could also be observed in investor and other stakeholder interest in CSR (Holder-Webb et.al. 2009). Much of the research interest in the field of finance in connection with CSR is directed towards the question if CSR will lead to a better financial performance. As mentioned before, in the existing literature, there is a consensus that suitable CSR programs will lead to value for the corporation. In fact, about seventy percent of the studies reviewed showed a positive and statistically relevant relationship between CSR and financial performance (Dilling 2009). McPeak and Tolley (2008) also state that well-managed CSR efforts can lead to an increase in financial performance. Martin Curran provides a systematic review of the evidence for the relationship between CSR and financial performance (Martin Curran 2005). For the purpose of this study, it is assumed that financial performance is positively related to the publication of a $\mathrm{G} 3$ report.

\section{Location}

There is conflicting evidence on the countries or regions that can be considered the most advanced regarding CSR and sustainability reporting. In the past, Europe was considered the most active reporting region, producing over half of the world's reports between 2001 and 2003. European sustainability reports were also considered to have the broadest coverage of non-financial issues and the highest proportion of reports placing reliance on external assurance (CGA Canada 2004). However, the KPMG 2008 study mentions that companies in Japan have topped the tables in rates of corporate responsibility reporting over the last decade (KPMG 2008). Finally, many other researchers found no actual difference in sustainability reporting between other countries which is usually interpreted as being the result of the convergence of corporate practices induced by the impact of the globalization of the stock markets (Cormier and Magnan 2003). Based on this assumption, for the purpose of this study it is hypothesized that there is no relationship between location and the publication of a G3 report. 


\section{RESEARCH METHODOLOGY}

\section{Sample Data and Collection}

In the first part of the research study, 100 matched companies have been examined by applying conditional logistic regression. This paper represents the second part of the research study in which 124 companies have been analyzed by applying univariate and multivariate logistic regression. The goal of the second part of this study is to establish if the level and/or presence of several corporate characteristics like industry, location, financial performance, corporate governance indicators, need for financing, etc., can predict the occurrence of the publication of a G3 sustainability report. The publication of a G3 report is interpreted as a serious commitment towards corporate sustainability. The question is if corporations that implement sustainability reporting in form of a G3 publication have distinct characteristics. It will also be very insightful to see if the results of the second study will confirm or complement the results of the first part using a different data analysis sample and approach.

A random sample of 74 corporations was selected from the GRI 2007 G3 report list (GRI 2008B) and 50 corporations were selected that did not prepare a G3 report. Those 50 non-G3 reporting corporations were listed as competitors of one of the 74 selected G3 companies. The data was taken from the corporate annual reports for the year 2007, data available at Reuters (Reuters 2009), Yahoo Finance (Yahoo Finance 2009), and proxy statements (EDGAR, SEDAR database and firm owned web pages).

The 124 firms included in the sample are located in 25 different countries, and engaged in 5 different main sectors. The main sector for 20 of the sampled companies was the energy sector, 36 engage in service activities, 37 in production, 25 in materials and mining, whereas 6 can be categorized into the equipment sector. The operating segments of all the organizations range from 1 to 10 while the geographic segments range from 1 to 15 . Between 350 to 387,000 employees worked for the examined companies. Total revenues ranged from 6 million US dollars to 524 billion USD. The highest value in terms of market capitalization in December 2008 was 2.7 billion USD. Thirty corporations raised new equity in 2007 while 50 issued long-term debt. Profit margins ranged from $-425 \%$ to $+66 \%$.

With regard to corporate governance, we observed 2 to 10 audit committee members and 4 to 22 board members. Audit committee meetings were held up to 28 times in the year 2007, while the board of director meetings ranged from 4 to 19. Two corporations did not provide information on audit committee meetings. Fourteen of the 124 corporation had formed specific sustainability committees while 68 had formed governance committees as part of their corporate governance structure. Ninety-two percent of corporations stated that they had a compensation committee. Institutional ownership ranged from zero to $95 \%$. Eighty-four of the corporations are headquartered in countries without any CSR legislation while 40 corporations are located in countries with some kind of CSR legislation (i.e., France, Denmark, Sweden, Spain, UK).

\section{Data Analysis and Results}

The association between G3 reports and firm characteristics was evaluated using the Fisher's exact test for dichotomous variables, the Pearson chi-square test for categorical variables and the student $t$-test for continuous variables.

According to the results shown in Table 1, it can be stated that the variables for main region, operating segments and corporate governance committee show a significant difference for the two related sample pairs. More specifically, there was a significant difference between the two group means for the variable main region ( $\mathrm{p}=0.016)$, number of operating segments $(\mathrm{p}=0.013)$, and corporate governance committee $(\mathrm{p}=0.018)$. There was no significant difference between G3 reporting and non-G3 reporting in CSR legislation, main sector, market capitalization, profitability ratios, capital structure or other corporate governance indicators than the corporate governance committee. 
Characteristics

\section{CSR legislated}

yes

no

Main region

Australia, Asia, Africa

Europe

North America

Main sector

Energy

Equipment

Materials \& Mining

Products

Services

Size

Market capitalization (in USD M)

Operating segments

Geographic segments

Employee numbers

\section{Profitability \& growth}

Profit margin

5 year growth sales

\section{Capital structure}

New equity issue in 2007

yes

no

New LT debt issue in 2007

yes

no

\section{Corporate governance}

Audit committee members

Audit committee meetings

Board of directors members

Board of directors meetings

Sustainability committee

yes

no

Governance committee

yes

no

*Pearson Chi square

$\sim$ 2-tailed t-test

" Fisher's exact test

\section{G3 (n=74)}

27

47

10

41

23

15

4

15

22

18

mean

36,052

4.55

4.6

72,232

11.85

11.41

$-1.65$

13.98

$0.143^{\sim}$

$0.197^{\sim}$

$0.416^{\prime \prime}$

16

58

32

42

4.28

6.8

12.47

8.67

11

63

34

40 p-value

$0.245^{\prime \prime}$

37

$0.016 *$

0.482 *

$0.417^{\sim}$

0.013

$0.519^{\sim}$

$0.740^{\sim}$
$0.420 "$

$0.420 "$

18

32

4.25

$0.913^{\sim}$

7.32

$0.442^{\sim}$

12.35

$0.852^{\sim}$

$0.852^{\sim}$

$0.156 "$

3

47

34

16

\section{$0.018 "$}


As mentioned above, the data was analyzed with univariate and multivariate logistic regression. Because of the nature of the dependent variable, we performed a binary univariate and multivariate logistic regression with a dichotomous outcome of G3 or non-G3 reporting ( 0 for control and 1 for G3 reporting cases) in relation to various firm variables, adjusting for other potential confounding factors. We estimated odds ratios and $95 \%$ confidence intervals. All statistical tests were considered significant at an alpha level of 0.05 (on a two-tailed test). The statistical software package SPSS 16.0 with add-on module regression was used (SPSS 2009).

Univariate logistic regression revealed significant associations between the independent variables operating segment $($ Chi square $=5.809, \mathrm{p}=0.016)$, profit margin $($ Chi square $=5.079, \mathrm{p}=0.024)$ and governance committee $($ Chi square $=5.952, \mathrm{p}=0.015)$ and the response variable. For the multivariate logistic regression, the model included G3 reporting as the dependent variable, and the independent variables profit margin, sales growth, long-term debt and equity issue, corporate governance and sustainability committee, region, market capitalization, operating and geographic segments, employee numbers, etc. All variables were included simultaneously in the same model to adjust for each other (Hosmer and Lemeshow, 2000). As can be seen in Table 2 below, G3 reporting was significantly associated with a non-CSR legislated and European location, the energy and product sector, profit margin and the 5 year growth percentage in sale revenues. The remaining variables were not associated with G3 reporting. The likelihood for a non-CSR legislated located firm to publish a G3 report is more than 27 times higher than for corporation located in a CSR-legislated country (odds ratio $(\mathrm{OR})=27.128,95 \%$ confidence interval $(\mathrm{CI})=$ 2.013-365.574, $\mathrm{p}=0.013$ ). Corporations located in Europe are 37 times more likely to produce a G3 report compared with those situated in a non-European country $(\mathrm{OR}=37.425, \mathrm{CI}=2.514-555.037, \mathrm{p}=0.009)$. Similarly, being a corporation in the energy sector increases the odds of a G3 report by a factor of 10.44 (OR=10.439, $\mathrm{CI}=1.738-62.695, \mathrm{p}=0.010)$. Corporations that are engaged in the product sector are 4.8 times likelier to produce a $\mathrm{G} 3$ report $(\mathrm{OR}=4.832, \mathrm{CI}=1.268-18.351, \mathrm{p}=0.021)$. With regard to profitability it can be stated that each additional percentage in profit margin increases the odds of a $\mathrm{G} 3$ report by $3.7 \%(\mathrm{OR}=1.037, \mathrm{CI}=1.001-1.075, \mathrm{p}=0.044)$. Further, each additional percentage in 5 year sales' growth decreases the odds of a G3 report by about $6 \%$ controlling for other variables in the model $(\mathrm{OR}=0.943, \mathrm{CI}=0.895-0.997, \mathrm{p}=0.041)$. The relatively small confidence intervals for the variables profit margin and sales growth indicate that the sample mean is close to the true mean. However, the relatively high upper limit for the confidence interval for the variables CSR legislation, main region and main sector indicates that the sample should be expanded to better draw conclusions.

As Table 2 below presents, overall, model goodness of fit was .262, as measured by McFadden's pseudo Rsquare. According to Green (Green, 2001), McFadden R-square values greater than .2 are considered to be a good fit. Based on the non-significant Hosmer and Lemeshow chi square goodness of fit test $(7.439, \mathrm{p}$-value $=0.49)$ it can be stated that the model adequately fits the data. The model has a high overall explanatory power with a model chi square of 43.87 with a p-value of 0.002. In addition, the model fit can be described as good since, according to the classification table, it successfully classifies $73.4 \%$ of the cases using a probability cut value of .5. In order to detect potential multicollinearity, the tolerance and variance inflation factor (VIF) for each independent variable were examined. Typically, in logistic regression, variance inflation factor values of above 2.5 are causes for concerns (Allison 1999). The tolerance values of all studied variables were relatively high (>.739) whereas the VIF values were low $(<1.354)$. This suggests that multicollinearity is very low in the suggested model.

\section{DISCUSSION}

In general, many of the findings are consistent with the first part of the research study. Our study findings in both parts show clearly that corporations that publish a G3 report have certain characteristics. The significant characteristics are related to CSR legislation, location, sector, and to the profitability and growth situation of the corporation. The fact that corporations located in countries without CRS legislation publish a G3 report seems to be logical. Since those requirements are not part of the legislation, corporations that consider CSR crucial to their success might be interested to show their CSR commitment to internal and external stakeholders by providing an extensive and standardized sustainability report in form of a G3 report. On the other hand, corporations located in countries with CSR legislation already in place might see no reason to prepare an additional sustainability report as this would mean that they have to allocate additional costs and resources in order to do so. 
Table 2: Multivariate Binary Logistic Regression

\begin{tabular}{|c|c|c|c|c|}
\hline Characteristics & $\begin{array}{l}\text { Log coefficient } \\
\text { B }\end{array}$ & odds ratio & $95 \% \mathrm{Cl}$ & $\begin{array}{l}\text { 2-tailed } \\
\text { p-value }\end{array}$ \\
\hline CSR legislated, no & 3.301 & 27.128 & $(2.013-365.579)$ & $0.013^{*}$ \\
\hline \multicolumn{5}{|l|}{ Main region } \\
\hline Australia, Asia, Africa & 0.759 & 2.135 & $(0.421-10.824)$ & 0.360 \\
\hline Europe & 3.622 & 37.425 & $(2.514-555.037)$ & $0.009 *$ \\
\hline \multicolumn{5}{|l|}{ North America (ref) } \\
\hline \multicolumn{5}{|l|}{ Main sector } \\
\hline Energy & 2.346 & 10.439 & $(1.738-62.695)$ & $0.010^{*}$ \\
\hline Equipment & 1.493 & 4.451 & $(.382-51.913)$ & 0.233 \\
\hline Materials \& Mining & 1.222 & 3.394 & $(0.863-13.347)$ & 0.080 \\
\hline Products & 1.573 & 4.823 & $(1.268-18.351)$ & $0.021 *$ \\
\hline \multicolumn{5}{|l|}{ Services (ref) } \\
\hline \multicolumn{5}{|l|}{ Size } \\
\hline Market capitalization & 0 & 1.0000 & $(1.000-1.000)$ & 0.355 \\
\hline Operating segments & 0.281 & 1.3250 & $(0.973-1.803)$ & 0.074 \\
\hline Geographic segments & 0.091 & 1.0960 & $(0.891-1.347)$ & 0.385 \\
\hline Employee numbers & 0 & 1.0000 & $(1.000-1.000)$ & 0.638 \\
\hline \multicolumn{5}{|l|}{ Profitability \& growth } \\
\hline Profit margin & 0.037 & 1.0370 & $(1.001-1.075)$ & $0.044^{*}$ \\
\hline 5 year growth sales & -0.058 & 0.9430 & $(0.892-0.998)$ & $0.041^{*}$ \\
\hline \multicolumn{5}{|l|}{ Corporate governance } \\
\hline Audit committee meetings & -0.009 & 0.9910 & $(0.863-1.138)$ & 0.897 \\
\hline Audit committee members & 0.116 & 1.1230 & $(0.763-1.652)$ & 0.556 \\
\hline Board meetings & 0.02 & 1.0200 & $(0.866-1.202)$ & 0.810 \\
\hline No sustainability committee & -1.065 & 0.3450 & $(0.058-2.046)$ & 0.241 \\
\hline No governance committee & 0.625 & 1.8680 & $(0.547-6.381)$ & 0.318 \\
\hline \multicolumn{5}{|l|}{ Capital structure } \\
\hline No new equity issue in 2007 & 0.203 & 1.2250 & $(0.378-3.975)$ & 0.735 \\
\hline No new LT debt issue in 2007 & -1.001 & 0.3680 & $(0.126-1.076)$ & 0.068 \\
\hline \multicolumn{5}{|l|}{ Reference category: last variable } \\
\hline${ }^{*}$ significant at $5 \%$ level & & & & \\
\hline
\end{tabular}

As mentioned before, previously, there have been inconclusive or contradictory research findings with regard to the association between location and sustainability reporting. Some of the previous research studies found that the European location is associated with CSR. The results of the study on hand are consistent with those studies (e.g., the 2004 CGA Canada study). In fact, the results of this study show that European corporations are 37 times likelier to produce a $\mathrm{G} 3$ report.

Earlier, we made the assumption that corporations in high-profile sectors will be more likely to provide sustainability reports due to the higher media exposure. The results of the data analysis confirm this assumption. It is shown that corporations active in the energy and the production sector are more likely to produce a G3 report. 
Therefore, the general assumption that energy and producing corporations provide better quality CSR information could empirically be confirmed.

The connection between financial performance and CSR has been much discussed and is an area of high interest for investors, shareholders, and academics in the field of finance and CSR. As seen previously in various empirical studies, this research study confirms the association between a higher profit margin and sustainability reporting. This association was confirmed in both parts of the research study.

As in the first part of the research paper, a negative association between long-term growth in sales and sustainability reporting was found in the data analysis. This seems to stand in contrast to Danchev (Danchev 2006) who stated that CSR will lead to long-term growth. It needs, however, to be determined at which developmental stage the corporation currently is. In order to find more powerful results, it is suggested that data for a longer range period should be examined.

Similar to the first part of the research study, no association was found between corporate governance variables and sustainability reporting. It can be stated that those findings were unexpected. Although we find a significant association for the variable sustainability committee for our matched sample, these results could not be confirmed for the second sample using a different analysis approach. We are hesitant to infer too much from null findings, however, it is also unexpected to find that the variables for size and capital structure were not related to G3 reporting.

\section{CONCLUSION AND FURTHER RESEARCH}

In the first part of this exploratory study, we found that the variables profit margin and sustainability committee are positively associated with the publication of a G3 report. However, the variables long-term growth in revenues and corporate governance committee were negatively associated with a G3 report. In the second part of the study, we found that no CSR-legislation, a European location, operating in the energy and product sector and the profit margin were positively associated with a G3 report while long-term growth in revenues was negatively associated with $\mathrm{G} 3$ reporting.

To our knowledge, this is the first study to explicitly examine the association of these key criteria, and performance and governance factors to sustainability reporting. There have been quite a few studies in which a link between profitability and sustainability has been examined. In fact, generally, more studies found a positive relationship between profitability and CSR than studies that find the opposite being true (Beurden and Goessling 2008). The study at hand supports the conclusion that has been drawn by the majority of researchers: firms that are more profitable are more likely to provide high quality sustainability reporting. Although there is a large body of research supporting the association of profitability and CSR, understanding the relationship between certain firm characteristics still remains a major challenge. Therefore, the causality of this relationship still needs to be researched in more detail (Haigh 2006).

According to the KPMG 2008 study, many companies still do not make the connection between corporate governance and CSR. In fact, only a small percentage of companies actually show a link between corporate governance and corporate responsibility in their reports. This study supports this impression as we are not able to find a significant association between corporate governance characteristics and sustainability reporting. With regard to the relationship of long-term growth in sales, it can be concluded that a corporation that experiences long-term growth is less likely to provide high quality sustainability reporting. As mentioned before, the opportunity for longterm growth depends very much on the status of the corporation on the CSR value chain. It seems that the organizations included in the study have not yet been able to experience the value creation that results from successful CSR implementation. On the contrary, the 5 year growth figure actually is negatively associated with the publication of a G3 report. The question that needs to be answered is when exactly the opportunities of this anticipated growth will be realized. Further research in this area is recommended.

As in all empirical studies there are some limitations that should be considered regarding future research in that area. The first limitation is sample size. A similar study with a bigger sample size is recommended to counteract 
this limitation, especially considering the confidence levels for the variables CSR legislation and location. Secondly, selection bias could have resulted in errors in the process of identifying the study population and selecting subjects. Finally, no distinction was made between the different self-declared application levels for the G3 reports. Further research should address all those limitations.

Clearly, there are still many remaining questions on this subject. However, despite these limitations, this study provides clear empirical support that sustainable corporations have certain characteristics. Global corporations need to realize the importance of realizing that CSR accompanied by sustainability reporting is a global concept with benefits to the corporation and its many stakeholders. As previously discussed, stakeholder pressures are believed to be the main driver of corporate social responsibility. In particular, shareholder pressures, government and regulatory requirements, and corporate reputation considerations are believed to be the three most important drivers of corporate social responsibility (CGA Canada 2004). If this is the case, the developments in European countries where we have growing CSR legislation will have a strong influence on the developments of CSR and resulting sustainability reporting practices. The integration of CSR into strategy, processes, communication, and the corporate governance structure is key. Only if the organization as a whole continuously stands behind the concept of high quality sustainability reporting, preferably in G3 format, the realization of long-term profit margins and long-term growth is possible.

Lastly, if 2009 really is the year of un-sustainability, as it has been claimed recently (Franklin 2008), it needs to be investigated if and how corporations react with regard to their CSR activities and to their sustainability reporting practices.

\section{AUTHOR INFORMATION}

Dr. Petra F.A. Dilling. After receiving her MBA in accounting at Simon Fraser University, Burnaby, Dr. Petra F.A. Dilling returned to her native Germany to study towards a PhD in accounting at the University in Frankfurt. Dr. Dilling has taught various courses in the field of accounting and finance at the undergraduate and graduate level. She worked in industry for several years and still is active as a consultant to the Certified General Accountant Association of Canada where she holds a professional accounting designation (CGA). Her research interests are in the field of sustainability reporting, CSR and financial performance, and voluntary disclosure.

\section{REFERENCES}

1. $\quad$ Allison, P.D. 1999, Logistic regression using the SAS system, SAS Institute, 1999.

2. Anonymous 2009. Denmark Mandates CSR Reporting. Business \& the Environment with ISO 14000 Updates 20, no. 2 (February 2009): 6-6. Business Source Complete, EBSCOhost (accessed March 27, 2009).

3. Anonymous 2003: Talking up corporate accountability. Business Europe 43, no. 13 (July 09, 2003 ): 1. Business Source Complete, EBSCOhost (accessed March 27, 2009).

4. Beurden, P. \& Gössling, T. 2008. The Worth of Values - A Literature Review on the Relation Between Corporate Social and Financial Performance. Journal of Business Ethics 82, no. 2 (October 2008): 407-424. Business Source Complete, EBSCOhost (accessed March 27, 2009).

5. Boyd, C. 2009. Sustainability is good business. The OECD Observer. < http://www.oecdobserver.org/news/fullstory.php/aid/546/Sustainability is good business.html>, accessed March 27, 2009.

6. Brundlandt Commission 1987: Our Common Future: Report of the World Commission on Environment and Development. March 20, 1987 <http://www.worldinbalance.net/agreements/1987-brundtland.php>, (accessed March 27, 2009).

7. Castelo Branco, M. \& Rodriguez Lima, L. 2006, Communication of corporate social responsibility by Portuguese banks: A legitimacy theory perspective. Corporate Communications: An International Journal 11, no. 3: 232-248. Business Source Complete, EBSCOhost (accessed March 22, 2009). 
8. CGA CANADA 2004: Measuring Up: A Study on Sustainability Reporting in Canada - A CGA-Canada report, viewed March 21, 2009, <http://www.cga-canada.org/enca/ResearchAndAdvocacy/AreasofInterest/SustainabilityReporting/Pages/ca_sustainability_exe_summary. aspx $>$ (accessed March 27, 2009).

9. The Commission To The European Parliament, The Council And The European Economic And Social Committee 2006, Implementing the partnership for growth and jobs: making Europe a pole of excellence on corporate social responsibility, <http://eurlex.europa.eu/LexUriServ/LexUriServ.do?uri=COM:2006:0136:FIN:EN:PDF>, (accessed March 27, 2009).

10. Cormier, D. \& Magnan, M. 2003. Environmental reporting management: a continental European perspective. Journal of Accounting \& Public Policy 22, no. 1 (January 2003): 43-62. Business Source Complete, EBSCOhost (accessed March 27, 2009).

11. CSR Quest 2009, Corporate sustainability.

<http://www.csrquest.net/default.aspx?articleID=13111\&heading>, (accessed March 27, 2009).

12. Danchev, A. 2006. Social capital and sustainable behavior of the firm. Industrial Management \& Data Systems 106, no. 7 (September 2006): 953-965. Business Source Complete, EBSCOhost (accessed March 27, 2009).

13. Delbard, O. 2008. CSR legislation in France and the European regulatory paradox: an analysis of EU CSR policy and sustainability reporting practice. Corporate governance, Vol. 8, No. 4, 2008, pp. 397-405, <http://www.eabis.org/index2.php?option=com_docman\&gid=159\&task=doc view\&Itemid=631, $>$, (accessed March 27, 2009).

14. Franklin, D. 2008. The year of unsustainability. Economist (December 21, 2008): 20-20. Business Source Complete, EBSCOhost (accessed March 31, 2009).

15. Garriga, E. \& Mele, D. 2004: Corporate Social Responsibility Theories: Mapping the Territory. Journal of Business Ethics 53, no. 1/2: 51-71. Business Source Complete, EBSCOhost (accessed March 22, 2009).

16. Green, W. H. 2001. Econometrics analysis. (4th ed.). Upper Saddle River, NJ: Prentice Hall.

17. GRI 2009A. About the GRI, <http://www.globalreporting.org/AboutGRI/WhoWeAre/>, (accessed March 27, 2009).

18. GRI 2009B. Briefing paper: Sustainability Reporting 10 Years On, <http://www.globalreporting.org/NR/rdonlyres/430EBB4E-9AAD-4CA1-9478FBE7862F5C23/0/Sustainability_Reporting_10years.pdf >, (accessed March 27, 2009).

19. IBM Institute for Business Value 2008: Feb 12, 2008, Attaining Sustainable growth through CSR < http://www-935.ibm.com/services/us/index.wss/ibvstudy/gbs/a1029293 >, (accessed March 27, 2009).

20. Haigh, M. \& Jones, M. 2006. The Drivers of Corporate Social Responsibility: A Critical Review. The Business Review, Cambridge 5, no. 2 (September 1, 2006): 245-251.

<http://www.proquest.com.arktos.nyit.edu/> (accessed March 27, 2009).

21. Hemingway, C. \& Maclagan, P. 2004. Managers' Personal Values as Drivers of Corporate Social Responsibility. Journal of Business Ethics 50, no. 1 (March 1, 2004): 33-44.

<http://www.proquest.com.arktos.nyit.edu/> (accessed March 27, 2009).

22. Hobson, S. 2005. Utilities lead the way in taking responsibility. Utility Week 23, no. 21 (June 24, 2005): 10-10. Business Source Complete, EBSCOhost (accessed March 27, 2009).

23. Homer D. \& Lemeshow S. 2000: Applied Logistic Regression. New York, John Wiley \& Sons, 2000.

24. Holder-Webb, L., et. al. 2009. The Supply of Corporate Social Responsibility Disclosures Among U.S. Firms. Journal of Business Ethics 84, no. 4: 497-527. Business Source Complete, EBSCOhost (accessed March 21, 2009).

25. Hoovers 2009. <www.hoovers.com>, (accessed March 21, 2009).

26. Kolk, A. 2008. Sustainability, accountability and corporate governance: exploring multinationals' reporting practices. Business Strategy and the Environment. 17, no. 1 (January 1, 2008): 1. http://www.proquest.com.arktos.nyit.edu/, (accessed March 27, 2009).

27. Kolk, A. 2003. Trends in sustainability reporting by the Fortune Global 250. Business Strategy and the Environment, 12, no. 5 (September 1, 2003): 279-291.

<http://www.proquest.com.arktos.nyit.edu/> (accessed March 27, 2009). 
28. KPMG 2008. KPMG International survey of corporate responsibility reporting 2008, $<$ https://www.kpmg.com/Global/IssuesAndInsights/ArticlesAndPublications/Pages/Sustainabilitycorporate-responsibility-reporting-2008.aspX $>$, (accessed March 21, 2009).

29. Martin Curran, M. 2005. Assessing the rate of return of the adoption of corporate social responsibility initiatives, $\mathrm{PhD}$ thesis, University of Edinburgh, UK.

30. Lankoski, L. 2008. Corporate responsibility activities and economic performance: a theory of why and how they are connected. Business Strategy and the Environment. 17, no. 8 (December 1, 2008): 547. http://www.proquest.com.arktos.nyit.edu/ (accessed March 31, 2009).

31. McPeak, C. \& Tooley, N. 2008. Do Corporate Social Responsibility Leaders Perform Better Financially? Journal of Global Business Issues. 2, no. 2 (July 1, 2008): 1-6. http://www.proquest.com.arktos.nyit.edu/ (accessed March 27, 2009).

32. Moneva, J. et. al. 2007: The corporate stakeholder commitment and social and financial performance. Industrial Management \& Data Systems 107, no. 1: 84-102. Business Source Complete, EBSCOhost (accessed March 22, 2009).

33. Nilsson, J. 2008. Investment with a Conscience: Examining the Impact of Pro-Social Attitudes and Perceived Financial Performance on Socially Responsible Investment Behavior. Journal of Business Ethics 83, no. 2: 307-325. Business Source Complete, EBSCOhost (accessed March 25, 2009).

34. Painter-Morland, M. 2006: Triple bottom-line reporting as social grammar: integrating corporate social responsibility and corporate codes of conduct. Business Ethics: A European Review 15, no. 4: 352-364. Business Source Complete, EBSCOhost (accessed March 22, 2009).

35. Porter, M. \& Kramer, M. 2006: Strategy \& Society: The Link Between Competitive Advantage and Corporate Social Responsibility. Harvard Business Review 84, no. 12: 78-92. Business Source Complete, EBSCOhost (accessed March 22, 2009).

36. REUTERS 2009. <www.reuters.com>. (accessed March 21, 2009).

37. Runhaar, H. \& Lafferty, H. 2009. Governing Corporate Social Responsibility: An Assessment of the Contribution of the UN Global Compact to CSR Strategies in the Telecommunications Industry. Journal of Business Ethics 84, no. 4: 479-495. Business Source Complete, EBSCOhost (accessed March 22, 2009).

38. SIRAN 2009. Sustainability Reporting by S\&P 100 Companies Made Major Advances From 2005-2007, <http://www.prnewswire.com/cgi-bin/stories.pl?ACCT=109\&STORY=/www/story/07-172008/0004851053\&EDATE>, (accessed March 21, 2009).

39. Stanny, E. \& Ely, K. 2008. Corporate environmental disclosures about the effects of climate change. Corporate Social Responsibility \& Environmental Management 15, no. 6 (November 2008): 338-348. Business Source Complete, EBSCOhost (accessed March 31, 2009).

40. Stephenson, A. 2009. The Pursuit of CSR and Business Ethics Policies: Is it a Source of Competitive Advantage for Organizations? Journal of American Academy of Business, Cambridge 14, no. 2 (March 1, 2009): 251-262. http://www.proquest.com.arktos.nyit.edu/ (accessed March 27, 2009).

41. Sweeney, L. \& Coughlan, J. 2008. Do different industries report Corporate Social Responsibility differently? An investigation through the lens of stakeholder theory. Journal of Marketing Communications 14, no. 2: 113-124. Business Source Complete, EBSCOhost (accessed March 21, 2009).

42. Upham, C. 2007. The Doctor Is In: Sustainability Reporting for Corporate Health, <http://www.greenbiz.com/blog/2007/08/09/the-doctor-is-in-sustainability-reporting-corporate-health>, (accessed March 21, 2009).

43. UN Conference on Environment and Development (1992), Agenda 21, <http://www.un.org/esa/sustdev/documents/agenda21/index.htm>, (accessed March 21, 2009).

44. Verheugen, G. 2005. Corporate Social Responsibility matters - tomorrow even more than yesterday or today, speech/05/348, CSR - Competitive Small Responsible: How Europe's small and medium sized enterprises are changing the face of responsible business conference, Brussels, June 142005.

45. Yahoo Finance 2009. <www.yahoo.com>, (accessed March 21, 2009). 